clinics, health centres, etc., might be transformed into aid posts. In some areas, it is suggested, the fixed posts should be supplemented by mobile units, which could give medical aid on the spot. Ambulances that may be required, the organization of ambulance services, and their personnel, are described, as well as the use and training of women for ambulance driving. Finally, the Minister urges all responsible authorities to press on with their schemes and proposals without delay, and desires that an interim report be furnished by every authority involved.

\section{The Placing of Children in Families}

The Advisory Committee of the League of Nations has issued a report upon this subject ("The Placing of Children in Families". Geneva, 1938. Vol. 1, price 3s. ; Vol. 2, price 5s. Messrs. Allen and Unwin, 40 Museum Street, W.C.1). To begin with, the Child Welfare Committee of the League planned a survey on the placing of children in families as part of its general inquiry into the treatment of neglected and delinquent minors, but it was afterwards decided to treat independently the whole problem of placing in families as a method of child care. The first volume of this report presents the principles accepted as underlying provisions for child care, the characteristic features of the different systems employed in various countries, and the organization of social services to direct 'placing'. Vol. 2 describes the various systems of placing children in families that are now employed in different parts of the world.

Buildings for the Academy of Sciences of the U.S.S.R.

A LARGE plaster-of-Paris model of the main new buildings of the Academy of Sciences of the U.S.S.R. is now on view at the Academy's premises in Bolshaya Kuluzhskaya Ulitsa in Moscow. The buildings were designed by A. V. Shchusev. The site for the buildings most favoured is on the Frunze Embankment of the Moscow River. The new buildings of the Academy, according to the plans, consist of five blocks with a volume of 880,000 cubic metres. In the centre of the architectural ensemble is the main block for the presidium of the Academy. The hall is large enough to seat 2,000 persons. There are also four smaller auditoriums. Near the main hall are rooms for the demonstration of films and for broadcasting; also a post and telegraphic office and an information bureau. A block has been set aside for the library and storage premises for fifteen million volumes. On either side of the block for the presidium are buildings to accommodate two museums, one of which will be the Natural History Museum.

\section{The Food and Drugs Act, I938}

THE Minister of Health has issued a circular to local authorities and public analysts on the new Food and Drugs Aet passed last July, which comes into force next October (Circular 1755. H.M. Stationery Office. 2d. net). This Act represents a great simplification of existing food and drugs law, some of which dates back to the sixteenth century, and opportunity has been taken to introduce, into the general law, provisions which have up to now been included only in Local Acts. Among new provisions which will become enforceable are the registration by local authorities of premises used for the sale or manufacture of ice cream and the preparation or manufacture of sausages or preserved food. Ice cream vendors must have their names and addresses on stalls, carts and barrows, and this requirement may be extended to all or any foods by the local authority. Slaughterhouses and knacker's yards will all in future be licensed for limited periods only, and new requirements are laid down as regards rooms, yards, etc., in which food is sold or prepared for sale.

\section{Earth Tremor in the Lipari Islands}

A STRONG earth tremor with epicentre near latitude $38^{\circ} 40^{\prime} \mathrm{N}$., longitude $15^{\circ} 7^{\prime} \mathrm{E}$. occurred during the night of January 27 and lasted several seconds according to human experience. The shock damaged several buildings, but no casualties are reported. The depth of focus is uncertain, but is unlikely to have been at the surface, as the shock was experienced and caused some apprehension in Messina. Messina has been troubled by earthquakes on several previous occasions, including February 25, 1509, June 8, 1599, March 28 and April 9, 1780, February 5-March 28, 1783 (six altogether), December 28, 1908, September 8,1905 , and October 23, 1907. The one on December 28,1908 , at $5 \mathrm{~h} .21 \mathrm{~m}$. was probably the most severe, nearly destroying Messina and Reggio, and causing the deaths of 77,283 people. On that occasion there were two epicentres in the Straits of Messina, the northerly one being the most important. The shock lasted 30 sec., caused sea-waves $38 \mathrm{ft}$. high at San Alessio, and subsidences of 22.9 in. two miles south of Reggio and 28 in. within two miles of Messina harbour.

\section{The Chilean Earthquake}

CHILE is one of the great seismically active regions in the world and part of the circum-Pacific ring of instability. During the night of January 24, an earthquake which lasted according to human experience for three minutes, shook an area greater than 40,000 square miles embracing Talca and Concepcion, and caused the deaths of approximately 15,000 people. It was the most severe for twelve years in Chile and the most destructive of human life since Quetta (India) in 1935. The three towns of Chillan, Pailalleque and Parral are reported completely destroyed; Concepcion, Talcahuano, San Rosendo and Los Angeles are severely damaged, and Talca, Angol, Lota and Curico damaged. At Talca the prison collapsed, fires broke out at the port of Talcahuano, the cathedral tower at Vaparaiso swayed dangerously, and half Concepcion is reported in ruins. From the available macroseismic evidence the epicentre appears to be near lat. $37^{\circ} \mathrm{S}$. and somewhat to the east of long. $73^{\circ} \mathrm{W}$. The shock appears to have had a normal focal depth and to have caused some surface faulting, and the railway line is reported damaged in several places, including one point about 12 miles south of Talca. Two trains are reported derailed.

CONCEPCION has had an unfortunate history seismically, having been severely damaged on no fewer than six occasions : February 9, 1570, March 15, 1657, July 8, 1730, March 25, 1751, February 20, 
1835, and July 23, 1898. The last was the least severe, but the five others were all accompanied by sea waves. On February 20, 1835, Concepcion was utterly ruined. The sea waves were $28 \mathrm{ft}$. and more in height, causing damage even as far north as Fernandez (420 miles). On this occasion the coast was raised by 4-5 ft., though it afterwards subsided by half that amount. The epicentre on the present occasion is probably farther inland than on former occasions, as most damage appears to have been done to the east of Concepcion and no sea waves are mentioned. The most active epicentre for moderate shocks recently appears to have been lat. $38 \cdot 0^{\circ} \mathrm{S}$., long. $73 \cdot 5^{\circ} \mathrm{W}$., which is a little to the south-west of the one suggested in the present instance, though more precise information concerning this latter must await the records of seismograms at observatories throughout the world.

\section{Announcements}

Prof. Arthur Conway, professor of mathematical physics in University College, Dublin, has been appointed by the Pope a member of the Pontifical Academy of Sciences to occupy the seat left vacant by the late Lord Rutherford.

Prof. P. G. H. Boswell, who has just retired. from the chair of geology in the Imperial College of Science and Technology, has been appointed emeritus professor of the College.

THE annual award of the Pittsburgh Section of the American Chemical Society has been made to Dr. George H. Clapp. The award, an aluminium plaque suitably inscribed, is made in recognition of outstanding service to chemistry in the Pittsburgh district. Dr. Clapp, who recently celebrated his eightieth birthday, directed, with Captain Hunt, the firm of Hunt and Clapp, which afterwards acquired the Pittsburgh Testing Laboratory. With Captain Hunt, Dr. Clapp was instrumental in bringing to Pittsburgh Charles $M$. Hall and in organizing the Pittsburgh Reduction Co., which is now the Aluminium Co. of America. Dr. Clapp's hobby is conchology.

Sir Frank Smirh, who has just retired from the post of secretary of the Department of Scientific and Industrial Research (NATURE, Jan. 14, p. 56), has taken up an appointment with the Anglo-Iranian Oil Co., Ltd., to advise on the company's research and development work.

As appeal will be broadcast from all national stations of the B.B.C. at 8.45 p.m. on Sunday, February 5, on behalf of UFAW (Universities Federation for Animal Welfare). This body differs from many having kindred objects in that its membership is drawn from the universities and includes a number of distinguished men of science, particularly biologists. The appeal will take the form of a dialogue between "Fougasse", the art editor of Punch, and the Hon. Harold Nicolson, M.P.

THE sixth International Congress of the Technique and Chemistry of Agricultural Industries will be held in Budapest on July 10-20.

Election to Beit Fellowships for scientific research will take place on or about July 7. Not more than three fellowships will be awarded. Applications must be received on or before April 6. Forms of applications and further information can be obtained from the Rector, Imperial College, South Kensington, London, S.W.

A Scandinavian Summer School in Norway and Sweden is being arranged by the Association for Education in Citizenship, to be held during August 5-22. The party will stay in colleges at Bommersvik, near Stockholm, and at Syverud, near Oslo. Lectures in English on the political, economic and educational developments taking place in their respective countries will be given by Norwegian and Swedish experts. Further information can be obtained from the secretary at the Association's offices, 10 Victoria Street, S.W.I.

THE annual joint meeting of the Institute of Radio Engineers and the International Scientific Radio Union (American Section) will be held in Washington, D.C., on April 28-29. Meetings of other scientific societies will be held in Washington during the same week including the National Academy of Sciences, American Physical Society and American Geophysical Union. Papers on the more fundamental and scientific aspects of radio will be presented. The programme will be published in the April issue of the Proceedings of the Institute of Radio Engineers. Further information can be obtained from S. S. Kirby, National Bureau of Standards, Washington, D.C.

THE annual malaria control course for laymen will be held at the London School of Hygiene and Tropical Medicine commencing on June 26. The course will be under the direction of Sir Malcolm Watson and the staff of the Ross Institute of Tropical Hygiene. The course lasts five days. It includes instruction on mosquitoes and their habits, drainage and other measures for the prevention of malaria. It is illustrated by lantern slides, films, demonstrations of the living insect in the various stages of its history, and a practical demonstration on Hampstead Heath. Application to attend the course, which is free, should be sent in as early as possible to the Organizing Secretary, Ross Institute of Tropical Hygiene, Keppel Street, Gower Street, London, W.C.1.

THE thirty-first annual general meeting of the Institute of Metals will be held in London on March 8-9. In addition to the usual list of papers to be read and discussed on the first day of the meeting, there will be two general discussions extending over the whole of the second day of the meeting. At the morning session the subject of debate will be "The Effect of Work on the Mechanical Properties of NonFerrous Metals", and in the afternoon the discussion topic will be "Industrial Application of Spectrography in the Non-Ferrous Metallurgical Industry". On March 8, the second annual award of the Institute of Metals Medal will be made, the recipient being Sir Harold Carpenter. The medal, which is of platinum, is the gift to the Council of the Institute, which decides its award, of the Mond Nickel Co., Ltd. The first award of the medal was made last year to Sir William Bragg. 